\title{
COVID-19 financing strategies for refugees and migrants in the Eastern Mediterranean Region
}

Elena Habersky ${ }^{1}$ and Aya Damir ${ }^{1}$

${ }^{1}$ Center for Migration and Refugee Studies, The American University in Cairo, Cairo, Egypt (Correspondence to: Elena Habersky: emhabersky@aucegypt. edu).

\begin{abstract}
Background: The COVID-19 pandemic has had devastating consequences on health care systems worldwide. While the world was slowly moving towards achieving health for all, the pandemic destroyed progress made over the past 25 years and exposed the vulnerability of health care systems and health insurance schemes as well as their lack of resilience. Heath care systems failed to respond in a timely and efficient manner, lives have been, and continue to be, lost and vulnerable populations, especially refugees and migrants, are more at risk than ever as many are left out of country vaccination programmes.
\end{abstract}

Aims: The Eastern Mediterranean region hosts 13 million internally displaced persons and 12 million refugees as of 2018 . Thus, adopting inclusive health financing mechanisms is crucial to addressing the crisis and protecting indigenous and displaced populations.

Methods: By looking at regional best practices and the response of the United Nations, we outline possible financing tools for including refugees and migrants in health insurance schemes for COVID 19 and introduce novel solutions for addressing gaps in funding.

Results: Among the suggested solutions are the inclusion of refugees and migrants in national health care systems, setting up community-based health insurance for migrant and refugee populations, as well as introducing a catastrophe bond financing scheme.

Conclusions: While COVID-19 is far from over, many countries in the EMR have included migrants in their COVID-19 vaccine rollout plans. While this is not the first instance of inclusion in some countries, many others are unable or do not prioritize migrants in their health systems, to the detriment of the entire country. This paper, therefore, tackles the possible health financing measures which curb or prevent migrants from accessing such systems and presents possible solutions to change the status quo.

Keywords: health care systems, refugees, migrants, health financing

Citation: Habersky E; Damir A. COVID-19 financing strategies for refugees and migrants in the Eastern Mediterranean Region. East Mediterr Health J. 2021;27(12):1229-1238. https://doi.org/10.26719/emhj.21.061

Received: 24/01/21, accepted: 15/06/21

Copyright (C) World Health Organization (WHO) 2021. Open Access. Some rights reserved. This work is available under the CC BY-NC-SA 3.o IGO license (https://creativecommons.org/licenses/by-nc-sa/3.o/igo).

\section{Introduction}

The COVID-19 pandemic has had devastating consequences on health care systems worldwide. The world was slowly moving towards achieving Health for All, however, the pandemic has destroyed progress made within the past 25 years and exposed the vulnerability of health care systems and health insurance schemes as well as their lack of resilience $(1,2)$. Heath care systems failed to respond to the pandemic in a timely and efficient manner; lives have been, and continue to be, lost and the vulnerable are at risk more than ever (3). The World Health Organization (WHO) Region for the Eastern Mediterranean (EMR) is no exception to that, with its 22 countries, 8 of which (Afghanistan, Iraq, Libya, occupied Palestinian territory, Somalia, Sudan, Syrian Arab Republic and Yemen) are experiencing serious conflicts and humanitarian emergencies, which aggravates the situation.

The countries of the EMR reported 6\% of the global count of COVID-19 cases, and most countries are in the community transmission phase as of 22 May 2021 (4). The Region faces a number of challenges in confronting the pandemic including: lack of reliable informationsharing mechanisms, inadequate tracing measures and high rates of virus transmission (5). The failure to adopt efficient infection prevention and control systems has resulted in an increase in the spread of the virus among health care workers (5). Additionally, the use of face masks varies significantly a cross the Region: approximately $6 \%$ in Palestine but almost $87 \%$ in Saudi Arabia as of 5 May 2021 (6). The Google COVID-19 mobility report has also shown various degrees in mobility: only 2 EMR countries have seen a reduction in mobility to grocery, pharmacies and entertainment sites, 5 saw a decrease in mobility to entertainment sites only, while 8 saw an increase to all types (7) (data were only available for 15 EMR countries; report date 27 May 2021). Entertainment sites include places like restaurants, cafes, shopping centers, theme parks, museums, libraries, and movie theaters.). Vaccination rates also remain extremely variable: while 
some countries have managed to vaccinate over $80 \%$ of their populations others have not been able to vaccinate $1 \%(8)$.

Other challenges faced by the Region include expanding public health measures, ensuring the sustainability of essential health services, and implementing reliable supply chains as all countries suffer from shortages of personal protective equipment, ventilators and diagnostics (5).

The situation in countries affected by conflicts and humanitarian emergencies is much worse. The supply of medical services has been disrupted and health facilities have been destroyed (9). Moreover, with the existing fragile health infrastructure and the minute human, capital and financial resources, responding to the pandemic in a timely and efficient manner has been a huge challenge. The median test rate per 100000 is merely 291 in conflict-affected countries compared with 15279 in other countries in the Region (5). Ongoing acts of violence threaten the existing health infrastructure, for instance where a 400-bed facility was bombed in Libya (9).

The pandemichas also had devastating socioeconomic consequences. Millions of households around the globe have lost their livelihoods, including informal employees who have no social protection, no access to adequate health care, nor the means to feed themselves. Countries of the Gulf Cooperation Council (GCC), Iraq, Jordan, Lebanon, Palestine, Syrian Arab Republicand Yemen, have incurred a loss of $14.65 \%$ in working hours on average, which accounted for 9 million jobs on average during the second and third quarters of $2020(10,11)$. It is also expected that the United Arab Emirates and Saudi Arabia will lose an additional 2.6 million jobs (11). Countries in protracted conflict situations are expected to suffer on a deeper level as their GDP may decline by $13 \%$, more than 2 times that in the rest of the Region (4.7\%), pushing thousands if not millions of people below the poverty line (5). The EMR countries host 13 million internally displaced persons and 12 million refugees as of 2018 ; this massive population deserves particular attention (12).

Migrant workers constituted $62-90 \%$ of reported cases in GCC countries at the beginning of the outbreak (5). Moreover, according to a study conducted by the Danish Refugee Council in Jordan, only 3\% of Syrian refugee households who were previously surveyed had one member working as opposed to $64 \%$ before the outbreak of the pandemic (13). Additionally, irregular migrants have been stranded; tens of thousands from India and Pakistan have lost their jobs in GCC countries. Nearly 200000 migrant Indian workers have registered to be repatriated from the United Arab Emirates a s of May 2020 (10). Furthermore, the future situation is expected to worsen: it has been estimated that more than 3.5 million migrant workers will be forced to leave GCC countries (14).

Living conditions are also affected: refugees living in camps and camp-like settings lack adequate access to hygiene facilities and running water (13). Likewise, migrants and refugees living in urban areas usually live in overcrowded dwellings facing the same terrible conditions, and with the loss of livelihoods, some are incapable of paying rent and have been evicted from their homes, making social distancing and COVID-19 precautions an unrealistic dream $(15,16)$. The inclusion of this staggering number of people in health care systems is of great importance and without it Health for All will not be achieved in the Region.

Given the devastating consequences of COVID-19 on migrant and host populations, the threat it continues to impose on their lives, and the need for allocating funds efficiently as well as harnessing international, regional, bilateral and national efforts to protect migrants, this paper aims to address the crisis effectively. Firstly, we outline general laws and policies regarding health care for refugees and migrants in the Region, practices in normal times, and specific programmes and measures adopted to confront the pandemic. Secondly, our paper addresses the financing mechanisms of these programmes and measures, international cooperation in support of EMR countries and the role of the United Nations and support by donor countries. Finally, the last section provides recommendations on the way forward as well as innovative and inclusive financial mechanisms and solutions.

\section{Regional situation}

\section{Overview}

Access to health care for refugees and migrants varies significantly across the Region. While they have free access to primary health care in Egypt, Iraq, Jordan, Lebanon and Tunisia, only regular migrants have access to health care in Morocco and the Syrian Arab Republic and this is provided by the state. On the other hand, in Bahrain, Kuwait, Qatar, Saudi Arabia and the United Arab Emirates, regular migrants are covered by their employers. In Oman health care is covered by the migrants themselves unless they come from the GCC countries but all migrants receive health care in life threatening situations. Health care in Yemen is provided by international donors and the United Nations Relief and Works Agency for Palestine Refugees in the Near East (UNRWA) provides primary health care services and selective tertiary care for Palestinians. In the wake of the COVID-19 pandemic Bahrain, Kuwait, Morocco, Saudi Arabia and the United Arab Emirates have passed laws allowing irregular migrants to regularize their status without paying a fine. However, it is important to look more closely at regional best practices in normal times and specific measures during the pandemic (12). 


\section{Regional best practices and response of national and international nongovernmental organizations}

As the world struggles with multiple waves of COVID-19, the EMR is no different to many countries which have implemented various forms of lockdown. While information in regard to health financing for refugees and migrants has been difficult to obtain since the onset of the pandemic, there are countries which incorporated these vulnerable populations into their health care systems pre-pandemic. This section will highlight 4 regional best practices for including refugees and migrants into health care systems and gives a brief synopsis of what national and international nongovernmental organizations have been doing to respond to the demand for increased health services since March 2020.

\section{Egypt}

\section{Situation}

Egypt, a country at the crossroa ds between Africa, Europe and the Middle East is accustomed to migration. Currently, the country is home to various migrant populations, including 258862 refugees and asylum-seekers of 57 different nationalities registered with the United Nations High Commissioner for Refugees (UNHCR) (17).

\section{Access for refugees and migrants}

A memorandum of understanding was signed between the Ministry of Health and Population and UNHCR in 2016, which allows refugees and a sylum-seekers in Egypt to have access to public primary and secondary health care as well as emergency treatment, equal to nationals (18). For migrants who have regular status, employers can provide private health insurance schemes or they can choose to access the public options. Failed asylum-seekers can access emergency health care services as under the Egyptian constitution no-one can be turned away from seeking emergency care, regardless of their legal status (19). While access to health care in law for refugees in Egypt is very good, access to health financing can be difficult. Although refugees and migrants can pay for private COVID-19 tests and hospitalization fees, many, especially refugees cannot afford them. Tests cost anywhere from 1500 to over 2000 Egyptian pounds per test and hospital rooms can run to over 20000 Egyptian pounds per night. Often government tests and hospitals for COVID are completely engaged, leaving many no other option than to go private. Some good news is that as of spring 2021, refugees registered with UNHCR and migrants are allowed to register for the vaccine, either AstraZeneca or Sinopharm, via the online vaccine registration portal of the Ministry of Health and Population.

\section{The Islamic Republic of Iran}

\section{Situation}

The Isla mic Republic of Iran is currently home to 979410 people of concern to UNHCR, predominantly from Afghanistan and Iraq (20), and is also home to one of the world's longest protracted refugee situations in modern day history with approximately 3 million Afghans residing in the country for the past 4 decades, both regularly and irregularly (21).

\section{Access for refugees and migrants}

Within the WHO EMR, the Islamic Republic of Iran has some of the most progressive policies when it comes to including refugee communities into its health care system. Since 2015, the country has included registered refugees and undocumented Afghans into its primary health care system and the national universal health care scheme (22). The scheme is supported by United Nations agencies and civil society actors. On the governmental side, the initiative is between the Ministry of Health and Medical Education, the Bureau for Aliens' and Foreign Immigrants' Affairs, the Iranian health insurance organization, and in close coordination with the Ministry of Health and Medical Education (23). The insurance programme "covers hospitalization, para-clinical and outpatient services, including doctor's visits, radiology, laboratory tests and medication costs incurred at any Ministry of Health-affiliated hospital and/or pharmacy" (23). Currently, UN$\mathrm{HCR}$, in collaboration with the Iranian government, is working on efforts to further extend the national health insurance scheme to refugees through subsidizing the insurance premium of identified extremely vulnerable refugees. For those not considered extremely vulnerable, durable solutions are being addressed to work on better affordability of the insurance premium (22), which is currently US\$ 11 per month (23). The Islamic Republic of Iran has also been progressive when it comes to COVID-19 for refugees and irregular migrants. According to UNHCR, "Thanks to Iran's inclusive policies, refugees and even undocumented foreign nationals affected by COVID-19 can approach hospitals and health posts and access free COVID-19 testing, treatment and hospitalization, in the same way as Iranian nationals" (24).

\section{Oman}

\section{Situation}

Oman continues to host large migrant populations, as it has for centuries. With an estimated population of 4.9 million, $41 \%$ of Oman's population is made up of migrants. Oman also hosts 308 refugees as of 2019 (25). As Oman is not party to the 1951 Refugee Convention and the subsequent 1967 Protocol, there are no national laws pertaining to the official status of asylum-seekers or refugees. Every resident of Oman who is a non-citizen falls under the domestic expatriate law (23).

\section{Access for refugees and migrants}

The health care system in the country is rapidly on a path to providing universal health care for all those residing within its borders. According to the Ministry of Health, the country spends about $3 \%$ of its national income on health care costs; however, more spending does not mean better quality, and the Ministry of Health is eager to increase the quality of its services with these funds (25). All public governmental and private health care services, 
which includes hospitals, clinics, institutes and medical colleges, are under the administration of the Ministry of Health, which issues ministerial decisions to regulate health care and ensures compliance with all laws and regulations (26). Under the universal health care system, all immigrants are included in the system and receive health care at subsidized prices in comparison with nationals who receive free primary health care (27). For those under 18 years, Royal Decree No 85/92 (28) and the approval of the Child Law RD 22/2014 (29) have ensured all children in the country receive health care free of charge. Oman also provides medical assistance to Yemenis fleeing the conflict in their home country and crossing the border into Oman. Political analysts in the country have expressed concern, though, of the toll this would take on the country: "It is not cheap to treat hundreds of people with bad injuries. Some of them stay in hospital for weeks. Some never return home because either they have no families to return to or have lost contact with them" (30). While Oman closed its borders to travellers from India, Bangladesh and Pakistan in April 2021 (31), all countries sending large numbers of migrants, it has previously come under fire for not doing enough for its many migrant workers, even treating its migrant health care staff as disposable (32).

\section{The United Nations response}

With the onset of COVID-19, many national and international nongovernmental organizations have appealed for funding to better equip countries hosting refugees and displaced populations with the services needed to fight COVID-19 directly. For some EMR countries the situation is dire as they struggle to provide services for their nationals, for example, in Somalia and Yemen. Other countries, like those mentioned above, already include refugees and other displaced populations into their health systems but may lack the resources needed to fulfil the quality services needed to combat a pandemic.

Currently, UNHCR Egypt, the Islamic Republic of Iran and Jordan have COVID-19 appeals. Although the UNHCR in the Islamic Republic of Iran has said there is no indication that refugees have been disproportionately hit by the virus, they may lose their access to livelihoods, causing a chain reaction to other issues, including affording basic needs (33). Likewise, UNHCR Egypt has mentioned the heavy toll COVID-19 has had on refugees, particularly with regard to loss of livelihoods. In addition, UNHCR Egypt has seen an increase in the incidence of gender-based violence as well as an increase in vulnerability for unaccompanied and separated children (34). These UNHCR offices have urgent appeals for millions in cash assistance.

In order to adequately respond to this crisis, WHO estimated a need of US\$ 1.7 billion until the end of December 2020 to adequately respond to COVID-19. As of 7 December 2020, US\$ 1.52 billion has already been received, with an additional US\$ 72.1 million pledged (35). In fact, WHO EMRO is being allocated US\$ 315 million of the total worldwide appeal (36). The UNHCR has a worldwide pledge for an additional US\$ 745 million in revised financial requirements until the end of 2020 with regard to addressing COVID-19 (37). In the EMR, UNHCR Egypt is asking for US\$ 10.2 million (38), while UNHCR Islamic Republic of Iran is asking for US\$ 16.2 million (33), both being part of the broader ask of UNHCR MENA, which is US\$ 343 million (38). The International Organization for Migration (IOM) hasa US\$ 618.9 million funding target, which will include 140 countries, under its COVID-19 Strategic Preparedness and Response Plan (39). To efficiently utilize the required funds and synergize actions to protect refugees and migrants, a number of recommendations are presented in the next section.

\section{Recommendations}

\section{Possible financing tools for COVID-19}

In order to create an inclusive health care financing mechanism against COVID-19, international organizations along with donors, national governments and civil society must cooperate to include refugees and migrants in their emergency planning. This can be done through a number of recommendations.

\section{Inclusion of migrants and refugees in national health care systems and services}

Encompassing refugees and migrants in primary health care and programmes to fight COVID-19, including vaccination, is a good public health policy as it protects the native population. Moreover, expanding primary health care to refugees and migrants on equal terms with nationals is important along with expanding primary health services and facilities through setting up respiratory clinics (40).

A number of strategies could be adopted to achieve their inclusion. Firstly, COVID-19 emergency funds and donations can be earmarked through including a percentage of expenditure towards health care for refugees and migrants and specific services which are of crucial importance to them such as hygiene facilities (running water, masks, etc.). On a national level it is advocated that governments create a COVID-19 supply bill in addition to the national budget, and account for migrants and refugee communities (40). This COVID-19 supply bill can be set up for fast-track expenditure and should be flexible enough to target specific frontline services and districts, including refugee camps and areas crowded with refugees and migrants. It is essential to set up accountable mechanisms for flexible expenditure systems and ensure it is based on "pay for performance" with defined goals and performance indicators and targets. The indicators should explicitly address refugees and migrants. Additionally, national systems could consider earmarking specific taxes, such as taxes on cigarettes, towards expenditure on COVID-19.

Secondly, integrating refugees in national health insurance systems, as the case with Afghan refugees in the Islamic Republic of Iran, or creating specific 
migrant and refugee health insurance programmes is proposed if their integration into national ones is not possible. In correspondence with the memorandum of understanding between Egypt and UNHCR, specific health clinics and hospitals could be responsible for providing refugees with health services. Refugee health insurance could be linked to attending awa reness-raising sessions on COVID-19 and insurance funds could be used to invest in frontline services in health care facilities used by refugees.

In order to implement such mechanisms practically, there are a number of suggested interventions. Health insurance should be provided to refugees and migrants with formal work contracts, either national health insurance or schemes set up specifically for migrant populations. An additional measure for those employing refugees and migrants during this pandemic would be setting up small group health insurance which is provided to groups of less than 50 employees or large group health insurance which covers more than 50 employees by private insurance companies. In the context of refugees, asylum-seekers and migrants who are informally employed, their integration into social health insurance could be achieved through setting a flat rate premium payment, i.e. their contribution could be based on a household flat income expectation rate, disregarding their wealth.

As refugees establish multiple community organizations, community-ba sed health insurance which covers refugees could be offered by insurance companies based on a flat rate/household premium. Rwanda's communitybased health insurance (Mutuelle de Santé) is a strong example (41). Through this scheme, persons and families from low income groups pay contributions of only 200 Rwandan francs or $10 \%$ of the total bill in order to receive medical care at an affordable cost, get refunded for medications, access primary and emergency health care and get treated at local medical facilities. The insurance covers all members of a household provided they have paid their contributions. Management of the scheme has been transferred from the Ministry of Health to the Rwanda Social Security Board and is supported by donors and the government.

Adopting a similar scheme for refugees would be beneficial. Community-based refugee organizations would come together to purchase this health insurance; it would cover members from low-income groups, prepayment would be compulsory, and it would be managed by the health ministry or a social security board. Refugee community group leaders would reach out to their members and networks to include them in this scheme. Funds collected would be pooled together with other community organizations until all funds have been pooled from refugees on a national level. This type of health insurance would cover the cost of testing and treatment for refugees. A similar scheme could be adopted for migrant workers. The UNHCR and IOM may consider paying the premiums from the resources they raise if the refugees are unable to contribute. Another solution would be to create a national social assistance programme for health offered to vulnerable populations (including failed asylum-seekers, irregular migrants and vulnerable refugees who are not able to contribute in order to cover COVID-19 expenses) and financed by contributions from international nongovernmental organizations and national governments.

\section{Setting up bond frameworlss which incorporate refugees and migrants}

As many international organizations increase funding requirements to deal with the onslaught of COVID-19, many of their yearly funding appeals remain severely underfunded, particularly those that deal with refugees, migrants and displaced populations. It is crucial that these vulnerable populations are included in these worldwide funding schemes for coronavirus and that donations to WHO EMRO, IOM, UNHCR and national and international nongovernmental organizations are increased.

In cooperation with the UNHCR and the IOM, WHO could issue refugee/migrant COVID-19 development impact bonds which would be similar to humanitarian impact bonds set up by the International Committee of the Red Cross (42). Investors, either national business owners or international businesses owners whose supply chain depends on migrants and refugee populations in an EMR country or a neighbouring country, can provide upfront capital for financing WHO COVID-19 programmes that target refugees and migrants. If predetermined measures of success have been achieved, then the investor would be repaid interest plus capital by an aid agency. If the required results were not achieved the investor would lose part of the capital invested. It is advised that the percentage of costs incurred by businesses/investors should be less than the losses these businesses would incur if they stopped operating. This could be calculated using estimations from previous waves of COVID-19.

Additionally, by creating viable pandemic insurance for companies employing a large number of migrants, once a parametric trigger has occurred (such as a specific decrease in revenues due to a pandemic, a shutdown in the city or an increase in the number of affected workers), the company would be indemnified. This could lead to a reduction in unemployment rates among migrants as it would discourage lay-offs; therefore, they can use their salaries to contribute in paying for COVID-19 treatment. However, this would need a large-scale increase in pandemic bonds, which are not currently abundant nor is this feasible (43).

Another instrument which could be set up is catastrophe bonds. The catastrophe (CAT) bond is a risk securitization instrument; these are issued to an investor by the government, an insurance company or any other entity. They are used to mitigate against a certain risk, and have been used mostly in the ca se of natural disa sters. They have high coupon rates and usually a maturity date 3-years from commencement. In case of the occurrence of a catastrophe, the investor defers or forfeits payment of the interest and/or principal, which is used to address 
the crisis. If it does not happen, the investor gets paid the interest and premium after the bond matures. Therefore payment to the investor is subordinated to payment to the insurer $(43,44)$.

These CAT bonds have been mentioned as a potential solution for responding to financing gaps for refugee crises. The only available pandemic risk securitization instrument is the Pandemic Emergency Financing Facility which is set up by the Work Bank. COVID-19 CAT bonds could provide an additional mea sure for COVID-19 treatment and prevention among migrant and refugee populations. In line with the Global Refugee Finance

\section{Figure 1 COVID-19 catastrophe (CAT) bonds financing scheme for refugees and migrants}

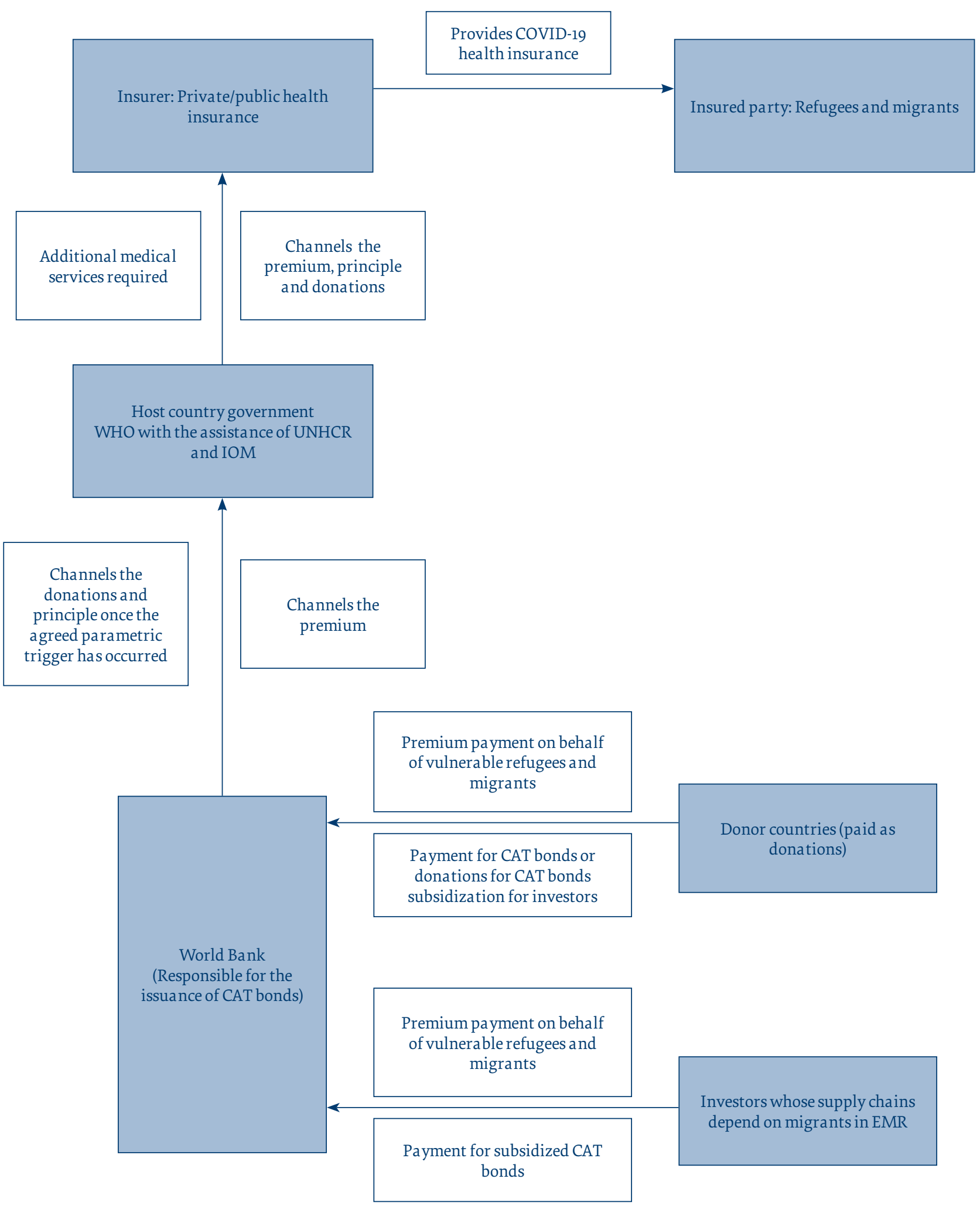


Catastrophe Bond and Humanitarian Catastrophe bond (42), CAT bonds could be considered as an ex ante instrument which means that the funds needed would be estimated based on last year's (2020) calculations. For the EMR, CAT bonds would be paid for by donor governments or investors in EMR countries through mapping international private sector investors whose supply chains depend on workers in the Region. In this case donor countries or the private investor would pay the premium on behalf of migrant and refugee populations (Figure 1). However, the value of the CAT bond payment by investors (the principle or premium) should be less than the losses they would incur if their business stopped operating, i.e. the risk of the spread of COVID-19 and lockdown. Thus, if donor countries subsidize the premiums or principle to investors, it might be more encouraging for them (40).
The receiving end could either be the host countries, WHO, UNHCR or IOM or their implementing organizations, which will deploy them towards providing health insurance. These funds would be available at the World Bank, which would be a second instrument to the Pandemic Emergency Financing Facility (see Figure 1). Another option would be having these funds as a public/ private trust fund this would depend on the preference of donor governments and investors. In turn, host countries would agree on measurable policy instruments. Thus, in order to release funds to EMR countries, certain metrics should be published such as the number of refugees and migrants and updated statistics on migrant and refugee populations affected by the pandemic. This in turn would help in spreading awareness of the need and access of migrant groups, especially refugees, to health services.

Funding: None.

Competing interests: None declared.

\section{Stratégies de financement en réponse à la COVID-19 pour les réfugiés et les migrants dans la Région de la Méditerranée orientale \\ Résumé}

Contexte : La pandémie de COVID-19 a eu des conséquences dévastatrices sur les systèmes de soins de santé partout dans le monde. Alors que le monde se rapprochait lentement de l'objectif de santé pour tous, la pandémie a anéanti les progrès réalisés au cours des 25 dernières années et a mis en évidence la vulnérabilité des systèmes de soins de santé et des régimes d'assurance-maladie ainsi que leur manque de résilience. Les systèmes de soins de santé n'ont pas réussi à réagir en temps opportun et de manière efficace. Des vies ont été et continuent d'être perdues, et les populations vulnérables, en particulier les réfugiés et les migrants, sont plus à risque que jamais, car nombre d'entre elles sont exclues des programmes de vaccination nationaux.

Objectifs : En 2018, la Région de la Méditerranée orientale comptait 13 millions de personnes déplacées internes et 12 millions de réfugiés. L'adoption de mécanismes inclusifs de financement de la santé apparaît donc cruciale pour faire face à la crise et protéger les populations autochtones et déplacées.

Méthodes : Nous nous sommes basés sur les meilleures pratiques régionales et la réponse des Nations Unies afin de décrire les outils de financement possibles pour inclure les réfugiés et les migrants dans les programmes d'assurancemaladie couvrant la COVID-19. Nous proposons aussi de nouvelles solutions pour combler les déficits de financement.

Résultats : Parmi les solutions proposées figurent l'inclusion des réfugiés et des migrants dans les systèmes de soins de santé nationaux, la mise en place d'une assurance-maladie à assise communautaire pour les populations de migrants et de réfugiés, ainsi que l'introduction d'un programme de financement en réponse aux catastrophes.

Conclusions : Alors que la pandémie de COVID-19 est loin d'être terminée, de nombreux pays de la Région de la Méditerranée orientale ont inclus les migrants dans leurs plans de déploiement des vaccins contre la COVID-19. Si certains pays n'en sont pas à leur coup d'essai en matière d'inclusion, de nombreux autres ne parviennent pas à intégrer les migrants dans leur système de santé ou n'en font pas une priorité, au détriment de l'ensemble du pays. Le présent document aborde donc les mesures de financement de la santé qui freinent ou empêchent les migrants d'accéder à ces systèmes et présente des solutions possibles pour changer le statu quo.

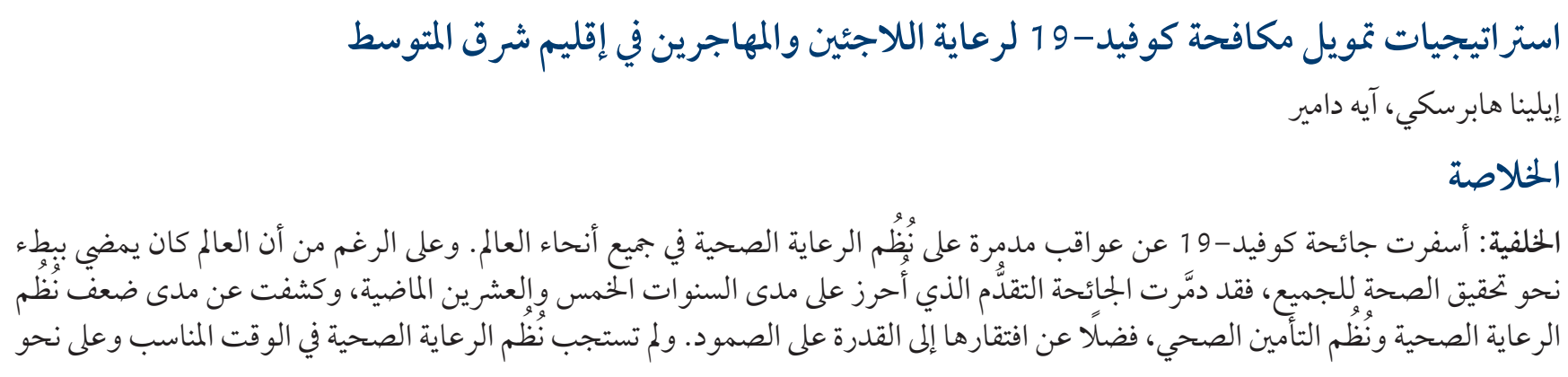




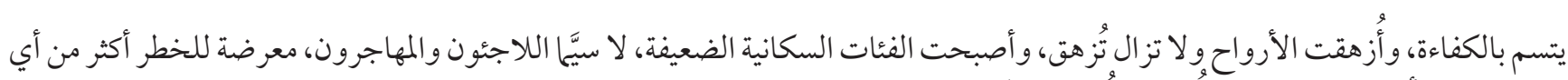

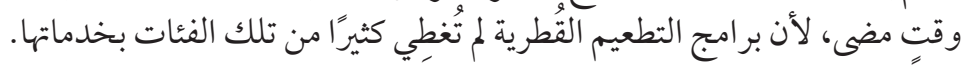

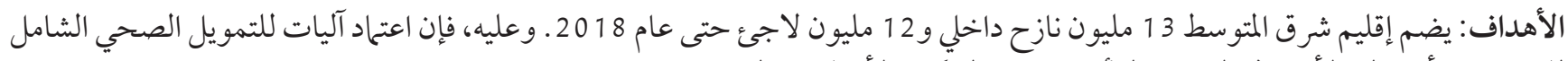

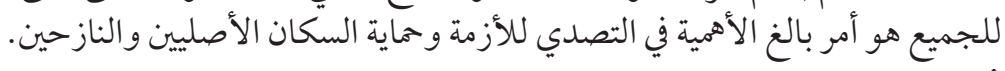

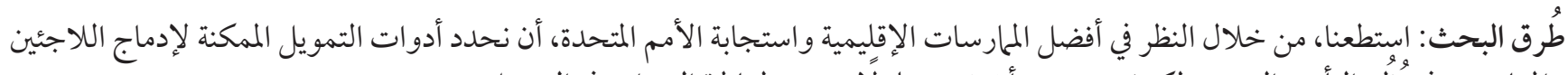

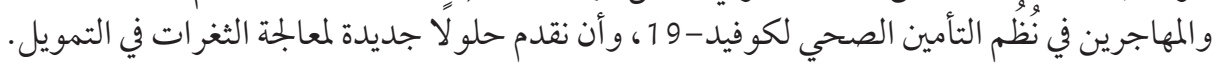

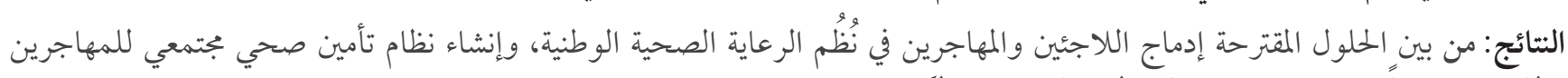

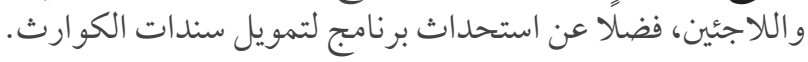

\section{References}

1. Responding to COVID-19 and building stronger health systems for universal health coverage. Geneva: World Health Organization; 2020 (https://www.who.int/news-room/fea ture-stories/detail/responding-to-COVID-19-and-building-stronger-health-systems-for-universal-health-coverage, accessed 24 August 2021).

2. COVID-19 dominates discussion of the 67th WHO Regional Committee for the Eastern Mediterranean. Cairo: World Health Organization Regional Office for the Eastern Mediterranean; 2020 (http://www.emro.who.int/media/news/COVID-19-dominates-discussion-of-the-67th-who-regional-committee-for-the-eastern-mediterranean.html, accessed 24 August 2021).

3. Impact of COVID-19 on people's livelihoods, their health and our food systems. Joint statement by ILO, FAO, IFAD and WHO, October 30, 2020. Geneva: World Health Organization; 2020 (https://www.who.int/news/item/13-10-2020-impact-of-COVID-19on-people's-livelihoods-their-health-and-our-food-systems, accessed 24 August 2021).

4. COVID-19 situation updates for week 20 (16-22 May 2021). Cairo: World Health OrganizationRegional Office for the Eastern Mediterranean; 2020 (http://www.emro.who.int/pandemic-epidemic-diseases/COVID-19/COVID-19-situation-updates-for-week20-1622-may-2021.html, accessed 24 August 2021).

5. Al-Mandhari AS, Brennan RJ, Abubakar A, Hajjeh R. Tackling COVID-19 in the Eastern Mediterranean Region. Lancet. 2020 Dec 5;396(10265):1786-1788. doi:10.1016/S0140-6736(20)32349-7

6. UMD global CTIS map. COVID-19 World Survey Map. College Park: University of Maryland; 2021 (https://COVIDmap.umd.edu/ map/, accessed 31 May 2021).

7. COVID-19 Mobility Reports. Google; 2020 (Internet) (https://www.google.com/COVID19/mobility/, accessed 30 November 2020).

8. WHO Regional Director's statement for virtual press briefing, 20 May May. Cairo: World Health Organization Regional Office for the Eastern Mediterranean; 2021 (http://www.emro.who.int/media/news/who-regional-directors-statement-for-virtual-pressbriefing-20-may.html, accessed 24 August 2021).

9. Attacks on healthcare in the context of COVID-19, 30 July, 2020. Geneva: World Health Organization; (https://www.who.int/ news-room/feature-stories/detail/attacks-on-health-care-in-the-context-of-COVID-19.html, accessed 24 August 2021).

10. İçduygu A. COVID-19 and the transformation of migration and mobility globally. Stranded irregular migrant workers during the COVID-19 crisis: the question of repatriation. Geneva: International Organization for Migration; 2020 (https://publications.iom. int/system/files/pdf/stranded-irregular.pdf, accessed 24 August 2021).

11. Impact of COVID-19 on migrants and refugees in the Arab region - technical paper. Geneva: International Organization; 2020 https://www.ilo.org/beirut/publications/WCMS_764756/lang--en/index.htm, accessed 24 August 2021).

12. WHO interim guidance note. Health system response to COVID-19 in the context of internally displaced persons, refugees, migrants and returnees in the Eastern Mediterranean Region. Cairo: World Health Organization Regional Office for the Eastern Mediterranean; 2020 (https://applications.emro.who.int/docs/EMCSR279E.pdf?ua=1\&ua =1, accessed 24 August 2021).

13. Protecting displaced during the COVID-19 crisis. Global appeal. Copenhagen: Danish Refugee Council; 2020 (https://drc.ngo/ campaigns/global-appeal-on-COVID/, accessed 30 November 2020).

14. Smith R, Zimmer C. The COVID-19 pandemic will probably not mark the end of the kafala system in the Gulf. Washington DC: Center for Global Development; 2020. https://www.cgdev.org/blog/COVID-19-pandemic-will-probably-not-mark-end-kafala-system-gulf, accessed 24 August 2021).

15. Hutton, J. Coronavirus exposes vulnerabilities of world's migrant workers. Singapore: The Straits Times; 26 May 2020 (https:// www.straitstimes.com/world/ middle-east/virus-exposes-vulnerabilities-of-worlds-migrant-workers, accessed 12 November 2020). 
16. Habersky E. Egypt's most vulnerable and COVID-19. Cairo, The Cairo Review of Global Affairs; 13 May 2020 (https://www.thecairoreview.com/midan/egypts-most-vulnerable-and-COVID-19/, accessed 24 August 2021).

17. Egypt Monthly Statistical Report. October 2020. Geneva: UNHCR; 2020 (https://www.unhcr.org/eg/wp-content/uploads/ sites/36/2020/10/September-2020-UNHCR-Egypt-Monthly-Statistical-Report-External.pdf, accessed 30 November 2020).

18. MoU signed with UNHCR for providing healthcare for refugees in Egypt. Cairo: ReliefWeb; 2016 (https://reliefweb.int/report/ egypt/mou-signed-unhcr-providing-healthcare-refugees-egypt, accessed 30 November 2020).

19. Hetaba A, McNally C, Habersky E. Cairo studies on refugee and migrants. Refugee entitlements in Egypt. Cairo: American University in Cairo, Center for Migration and Refugee Studies; 2020 (https://documents.aucegypt.edu/Docs/GAPP/Refugee-Entitlements-Report\%202.0.pdf. accessed 30 November 2020).

20. Fact sheet. Iran. April - June 2020. Geneva: UNHCR; 2020 (https://reporting.unhcr.org/sites/default/files/UNHCR\%20Iran\%20 Fact\%20Sheet\%20-\%20Apr-Jun\%202020.pdf, accessed 1 December 2020).

21. Jauhiainen J, Eyvazlu D, Sarcheshmeh BS. Afghans in Iran: migration patterns and aspirations. Turku, Finland: University of Turku, Department of Geography and Geology; 2020 (https://www.researchgate.net/publication/339253116_Afghans_in_Iran_ Migration_patterns_and_aspirations, accessed 24 August 2021).

22. Iran Operational Update. December 17, Geneva: UNHCR; 2019. Accessed December 1, 2020. https://reporting.unhcr.org/ node/2527?y=2020\#year, accessed 1 December 2020).

23. Health of refugees and migrants: practices in addressing the health needs of refugees and migrants. WHO Eastern Mediterranean Region 2018. Geneva: World Health Organization; (https://www.who.int/migrants/publications/EMRO-Practices.pdf?ua=1, accessed 24 August 2021).

24. How UNHCR is supporting Iran in the fight against COVID-19. Tehran: UNHCR Iran; 2021 (https://www.unhcr.org/ir/COVID-response-iran/\#: :text=Thanks\%20to\%20Iran's\%2oinclusive\%20policies,same\%20way\%20as\%20Iranian\%2onationals, accessed April 19, 2021).

25. Population, total - Oman. World Bank | Data. Washington DC: World Bank; 2019 (https://data.worldbank.org/indicator/SP.POP. TOTL?locations=OM\&view=chart, accessed 28 December 2020).

26. Health laws and regulations. Muscat: Omanuna, the Official Oman EGovernment Services Portal; 2020 (https://omanportal.gov. om/wps/portal/index/cr/childcare/childprotectionlaws, accessed 28 December 2020).

27. Oman's healthcare system increa singly ready to meet the population's needs. London: Oxford Business Group; 2017 (https:// oxfordbusinessgroup.com/overview/rise-growing-population-finds-health-care-system-ready-meet-its-needs, accessed 28 December 2020).

28. Child Protection Laws. Muscat: Omanuna, the Official Oman EGovernment Services Portal; 2019 (https://omanportal.gov.om/ wps/portal/index/cr/childcare/childprotectionlaws, accessed 28 December 2020).

29. Child law. Muscat: Sultanate of Oman; 2014. Accessed December 28, 2020 (https://omanportal.gov.om/wps/wcm/connect/1eeb3c81-a 913-48e6-bf45-8fc19f3101dd/Child law (Arabic).pdf?MOD=AJPERES, accessed 28 December 2020).

30. Al Shaibany S. Oman provides sanctuary for Yemenis fleeing conflict. The National. March 05, 2017 (https://www.thenational.ae/ world/oman-provides-sanctuary-for-yemenis-fleeing-conflict-1.30420, accessed 28 December 2020).

31. HT Correspondent. UAE, Oman, Australia impose travel curbs on India amid massive COVID-19 surge. Hindustan Times, April 222021. (https://www.hindustantimes.com/india-news/ua e-oman-australia-impose-travel-curbs-on-india-amid-ma ssive-COVID19-surge-101619112051201.html, accessed 22 April 2021).

32. Owtram F, Profanter A, Maestri E. In Oman, no security for the migrant health workers fighting the pandemic. Open Democracy. 23 July 2020. (https://www.opendemocra cy.net/en/north-africa-west-a sia/in-oman-no-security-for-the-migrant-health-workers/, accessed 24 August 2021).

33. UNHCR Iran COVID response in the Isla mic Republic of Iran August 2020. Tehran: UNHCR Iran; 2020 (https://reporting.unhcr. org/sites/default/files/UNHCR\%20COVID\%2oresponse_Aug\%202020.pdf, accessed 24 August 2021).

34. El-Demerdash Y. COVID-19 takes heavy toll on refugees in Egypt. Cairo: UNHCR Egypt; 2020 (https://www.unhcr.org/eg/16453COVID-19-takes-heavy-toll-on-refugees-in-egypt.html, accessed 24 August 2021).

35. COVID-19 Contributions tracker. Geneva: World Health Organization; 2020 (https://www.who.int/emergencies/diseases/novel-coronavirus-2019/donors-and-partners/funding, accessed 30 November 2020).

36. COVID-19 WHO appeal. Geneva: World Health Organization; 2020 (https://www.who.int/publications/m/item/COVID-19-whoappeal, accessed 24 August 2021).

37. COVID-19 situation. Geneva: UNHCR Global Focus; 2020 (https://reporting.unhcr.org/COVID-19, accessed 24 August 2021).

38. Coronavirus pandemic exacerbates challenges for refugees in Egypt. Cairo: ReliefWeb (UNHCR) 2020 (https://reliefweb.int/ report/egypt/coronavirus-pandemic-exa cerbates-challenges-refugees-egypt, accessed 24 August 2021).

39. IOM response to COVID-19. Geneva: International Organization for Migration; 2020 (https://www.iom.int/COVID19 t, accessed 24 August 2021).

40. Barroy H, Wang D, Pescetto C, Kutzin J. How to budget for COVID-19 response? A rapid scan of budgetary mechanisms in highly affected countries. Geneva:World Health Organization; 2020 (https://smj.org.sa/content/smj/41/4/440.full.pdf, accessed 24 August 2021). 
41. Community based health insurance (CBHI). Kigali, Rwanda: Rwanda Social Security Board; 2020 (https://www.rssb.rw/index. php?id=17, accessed 24 August 2021).

42. International Rescue Committee. Innovative Financing for Responses to Refugee Crisis. ReliefWeb (OCHA); 2019 (https://reliefweb.int/report/world/innovative-financing-responses-refugee-crises, accessed 24 August 2021).

43. Schwarcz SL. Insuring the 'Uninsurable': catastrophe bonds, pandemics, and risk securitization. Wa shington University Law Review. 2021-2022;99:Duke Law School Public Law \& Legal Theory Series No. 2020-71 (https://papers.ssrn.com/sol3/papers. cfm?abstract_id=3712534, accessed 24 August 2021).

44. Spiegel P, Chanis R, Trujillo A. Innovative health financing for refugees. Spiegel P, Chanis R, Trujillo A. Innovative health financing for refugees. BMC Med. 2018 Jun 15;16(1):90. doi:10.1186/s12916-018-1068-9 